Original Research

\title{
Spatial Distribution and Pollution Assessment of Potentially Toxic Elements in Urban Forest Soil of Nanjing, China
}

\author{
Junye Zhang1, ${ }^{1,}$ Fei Yü ${ }^{3}$, Shaodong Pang ${ }^{1}$, Yuanchun Yu ${ }^{1 *}$ \\ ${ }^{1}$ Co-Innovation Center for Sustainable Forestry in Southern China, College of Biology and the Environment, Nanjing \\ Forestry University, Nanjing, P.R. China \\ ${ }^{2}$ Henan Polytechnic, Zhengzhou, P.R. China \\ ${ }^{3}$ Jiangsu Polytechnic College of Agriculture and Forestry, Jurong, P.R. China
}

Received: 12 March 2018

Accepted: 3 July 2018

\begin{abstract}
Our study aimed to assess the pollution levels and ecological risk of potentially toxic elements (PTEs): $\mathrm{Pb}, \mathrm{Cd}, \mathrm{Cu}, \mathrm{Cr}, \mathrm{Zn}, \mathrm{Ni}$, and As in the urban forest soil of Nanjing, China. A total of 180 topsoil $(0 \sim 20 \mathrm{~cm})$ samples were collected with the aid of GPS according to $1 \times 1 \mathrm{~km}$ grid cells in six different function zones: road green belt (RGB), urban square (US), urban garden (UG), institution greenland (IG), residential greenland (RG), and urban rural forest (URF). The concentrations of seven PTEs in study areas were higher than their background values (BVs), and three anthropogenic origins were identified: industrial origin, traffic origin, and agricultural origin by principle analysis (PCA), coupled cluster analysis (CA), and kriging interpolation. The potential ecological risk index (PERI) in the Nanjing urban forest soils was 305.62 , in a state of significant pollution, which was mainly due to high contents of $\mathrm{Pb}$, $\mathrm{Cd}, \mathrm{As}$, and $\mathrm{Zn}$ by correlation analysis. There were three distribution patterns for seven PTEs and PERI: $\mathrm{Pb}, \mathrm{Cd}, \mathrm{As}$, and PERI presented similar island pattern which took traffic and commercial center as a hot spot (TCIP), while Cr and Ni presented an island pattern that took chemical plants as hotspot (CPIP), and $\mathrm{Cu}$ and $\mathrm{Zn}$ presented a scattered point pattern (SPP).
\end{abstract}

Keywords: urban forest soil, potentially toxic elements, spatial distribution, pollution assessment, potential ecological risk index

\section{Introduction}

With rapid development of industrialization and urbanization, potentially toxic elements (PTEs) contamination has become a popular problems in

*e-mail: 122418810@qq.com
China. Many researchers have studied the effects of PTE contamination in agricultural soils [1-2]. Some elements are necessary or beneficial to plants at certain levels, such as $\mathrm{Cu}, \mathrm{Zn}$, and Ni. Fertilization with $\mathrm{Zn}$ improves water use efficiency, grain yield, and content of seed $\mathrm{Zn}$ in chickpea [3], and the experiments conducted at a total of 23 experimental site-years in China, India, Kazakhstan, Mexico, Pakistan, Turkey, 
and Zambia also showed foliar $\mathrm{Zn}$ application alone or in combination with soil application, significantly increasing the concentration of grain $\mathrm{Zn}$ from 27 to $48 \mathrm{mg} \cdot \mathrm{kg}^{-1}$ across all the 23 site-years, which resulted in an increase in grain $\mathrm{Zn}$ by $84 \%$ and $90 \%$, respectively [4]. Field experiments conducted in soil on $\mathrm{Cu}$-deficient soil near the Porcupine Plain in northeastern Saskatchewan showed that the increase in concentration and uptake of $\mathrm{Cu}$ in grain from $\mathrm{Cu}$ fertilization usually showed a similar trend to grain yield [5]. Nikoli used five methods to extract $\mathrm{Ni}$ from cultivated soils, the result showed that sufficiency critical levels of $\mathrm{Ni}$ in soil were approximately $2 \mathrm{mg} \cdot \mathrm{kg}^{-1}$, which was probably a good guide to indicate soils that will respond to $\mathrm{Ni}$ fertilization [6]. Also, excessive amounts of $\mathrm{Cu}, \mathrm{Zn}$, and $\mathrm{Ni}$ retard plant growth [7-9]. Some elements are not essential for plant growth, and are poisoning plants when contents accumulated to a certain degree. $\mathrm{Pb}, \mathrm{Cd}$, and $\mathrm{Cr}$ are common heavy metals, and their stress will produce different degrees of damage. PTEs have strong influence on nutrition values, therefore plants grown on metal-contaminated soil were nutrient deficient, and consumption of such vegetables may lead to nutritional deficiency in the population - particularly when living in developing countries that are already facing nutrition problems [3]. Pot culture experiments of Zea mays L. showed that growth response of Zea mays L. was considerably influenced by interaction of $\mathrm{Cd}$ and PCP, significantly declining with either $\mathrm{Cd}$ or PCP additions [10]. Research about Hibiscus Sabdarifa showed that beyond $10 \mathrm{mg} \cdot \mathrm{kg}^{-1}$ of $\mathrm{Cr}$ in soil was toxic to the plants and resulted in a significant a reduction in the growth of plants [11]. Arsenic is a carcinogenic metalloid that occurs in the environment in a variety of chemical forms, showing different mobility, bioavailability, and toxicity [12], and a global data analysis shows that rice grain arsenic concentrations increase with increasing soil arsenic concentration until about $60 \mathrm{mg} \cdot \mathrm{kg}^{-1}$ and then decrease [13]. The PTEs in agricultural soil also accumulate in plants, absorbed by human body through food chain and harm human health [14-16]. All seven of these PTEs are common in urban environments for traffic pollution [17], industrial discharge [18], extensive use of fertilizers and pesticides [19], and soil parent materials [20]. The PTEs accumulated in urban soil affect the growth of urban plants [21] and weaken the regulating function of urban ecological environment on one hand [22], while on the other hand they enter and harm the human body through road dust and by rainfall into the atmosphere and underground water [23].

Here we aimed to assess the pollution levels of seven PTEs in the urban forest soils in Nanjing, China. $\mathrm{Pb}, \mathrm{Cd}$, $\mathrm{Cr}, \mathrm{Zn}, \mathrm{Cu}, \mathrm{Ni}$, and As concentrations in the different function zones and their spatial distribution were discussed in relation to possible influence of land use. We used three indexes to assess the potential ecological risk level.

\section{Material and Method}

\section{Soil Sampling}

The study was conducted in Nanjing (118 $\left.22^{\prime} \mathrm{E}-119^{\circ} 14^{\prime} \mathrm{E}, 31^{\circ} 14^{\prime} \mathrm{N}-32^{\circ} 37^{\prime} \mathrm{N}\right)$, Jiangsu Province - a rapidly urbanizing city in eastern China near the Yangtze river. The soil for analysis PTEs was sampled in 2015 from urban forest encircled by the NingLuo Highway, the HuRong Highway, and Jiangbei Avenue in the center of Nanjing. 180 topsoil samples $(0 \sim 20 \mathrm{~cm})$ were collected across the area with the aid of GPS, distributed in downtown Nanjing (Fig. 1) with grid cells of $1 \times 1 \mathrm{~km}$. Each composition sample from the sampling sites consisted of five subsamples. The soils
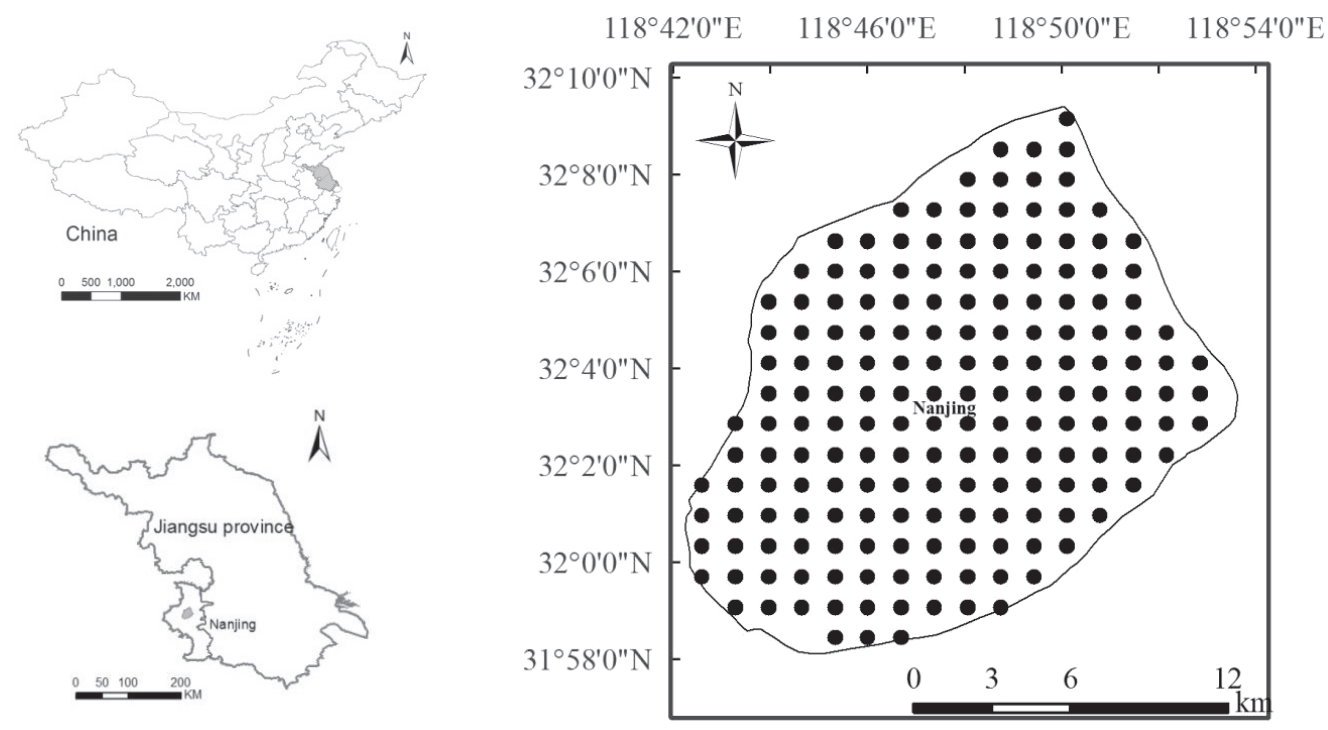

Fig. 1. Study area location and sampling sites in Nanjing. 
Table 1. Three indexes to assess PTE pollution.

\begin{tabular}{|c|c|c|c|}
\hline Index & Formula & Meanings of each letter & Assess \\
\hline $\mathrm{P}_{\text {in }}$ & $\begin{array}{l}P_{\text {in }}=\sqrt{\frac{\left(\frac{1}{\mathrm{n}} \sum_{i=1}^{n} P_{i}\right)^{2}+P I_{i \max }^{2}}{2}} \\
P_{\mathrm{i}}=\frac{C_{i}}{S_{i}}, P_{i \max }=\frac{C_{i \max }}{S_{i}}\end{array}$ & $\begin{array}{l}\mathrm{P}_{\mathrm{i}} \text { : environmental quality index of pollutant; } \\
\mathrm{C}_{\mathrm{i}} \text { : measured mass fraction of pollutant } \\
\qquad\left(\mathrm{mg} \cdot \mathrm{kg}^{-1}\right)\end{array}$ & $\begin{array}{c}\mathrm{P}_{\text {in }}<0.7 \text {, Safe } \\
0.7 \leq \mathrm{P}_{\text {in }}<1 \text {, vigilance } \\
1 \leq \mathrm{P}_{\text {in }}<2 \text {, clean-light pollution } \\
2 \leq \mathrm{P}_{\text {in }}<3 \text {, moderate pollution } \\
\mathrm{P}_{\text {in }}>3 \text {, strong pollution }\end{array}$ \\
\hline \multirow{5}{*}{$\mathrm{I}_{\mathrm{geo}}$} & \multirow{5}{*}{$\mathrm{I}_{\mathrm{geo}}=\log _{2}\left(\frac{C_{i}}{1.5 B_{i}}\right)$} & \multirow{5}{*}{$\begin{array}{l}\mathrm{C}_{\mathrm{i}} \text { : measured value of the heavy metal i } \\
\qquad\left(\mathrm{mg} \cdot \mathrm{kg}^{-1}\right) ; \\
\mathrm{B}_{\mathrm{i}}: \text { background value of PTE i }\left(\mathrm{mg} \cdot \mathrm{kg}^{-1}\right)\end{array}$} & $\mathrm{I}_{\text {geo }}<2$, clean-light pollution \\
\hline & & & $2 \leq \mathrm{I}_{\text {geo }}<5$, moderate pollution \\
\hline & & & $5 \leq \mathrm{I}_{\text {geo }}<20$, significant pollution \\
\hline & & & $20 \leq \mathrm{I}_{\mathrm{geo}}<40$, strong pollution \\
\hline & & & $\mathrm{I}_{\text {geo }} \geq 40$, extreme pollution \\
\hline PERI & $\begin{array}{l}\text { PERI }=\Sigma E_{\mathrm{i}} \\
\mathrm{E}_{\mathrm{i}}=\mathrm{T}_{\mathrm{i}} \frac{C_{i}}{B_{i}}\end{array}$ & $\begin{array}{l}\mathrm{E}_{\mathrm{i}} \text { : ecological risk of single heavy metal } \mathrm{i} \text {; } \\
\mathrm{T}_{\mathrm{i}} \text { : toxic-response factor for heavy metal } \mathrm{i} \text {; } \\
\mathrm{C}_{\mathrm{i}} \text { : measured value of PTE } \mathrm{i}\left(\mathrm{mg} \cdot \mathrm{kg}^{-1}\right) \text {; } \\
\mathrm{B}_{\mathrm{i}} \text { : background value of PTE } \mathrm{i}\left(\mathrm{mg} \cdot \mathrm{kg}^{-1}\right)\end{array}$ & $\begin{array}{c}\mathrm{RI}<150 \text {, clean-light pollution } \\
150 \leq \mathrm{R}<300 \text {, moderate pollution } \\
300 \leq \mathrm{R}<600 \text {, significant pollution } \\
\mathrm{RI} \geq 600 \text {, extreme pollution }\end{array}$ \\
\hline
\end{tabular}

were collected from neighboring areas once there were buildings or water on the designated position. Each soil sample was obtained with a wooden shovel and packed into polyethylene. The locations of sampling sites were recorded, including environmental information and land use, which were divided into 6 function zones according to their land use: road green belt (RGB), urban square (US), urban garden (UG), institution greenland (IG), residential greenland $(\mathrm{RG})$, and urban rural forest (URF).

\section{Determination of PTEs}

Soil samples were placed on a wooden plate and airdried at room temperature. Root, stem, leaf, worm and stones, and tuberculosis (lime, iron, manganese) were picked up. Dried soil samples in wooden discs were crushed, sieved through a 100-mesh nylon sieve, and loaded in a brown paper bag for analysis.

The sample digestion method was as follows: accurately weighing $0.5000 \mathrm{~g}$ (accurate to $0.0001 \mathrm{~g}$, the same as below) dry soil samples in the Teflon crucible, plus $20 \mathrm{~mL} \mathrm{HNO}_{3}$, then heating to being almost sticky on an electric heating plate, added $20 \mathrm{~mL} \mathrm{HF}$ and continue heating, often shaken in a crucible to almost sticky, with added $20 \mathrm{~mL} \mathrm{HCLO}_{4}$, heated to no longer making white smoke, with added water to rinse the lining and the crucible lid, tepid digestion residue, after cooling, added water up to $100 \mathrm{~mL}$. $\mathrm{HNO}_{3}, \mathrm{HF}$, and $\mathrm{HCLO}_{4}$ are guaranteed reagents, and the water used in the experiment is ultra pure.

Determining $\mathrm{Pb}, \mathrm{Zn}, \mathrm{Cu}, \mathrm{Cr}, \mathrm{Cd}, \mathrm{Ni}$, and $\mathrm{As}$ in soil was carried out by ICP-OES analysis, and recommended wavelengths of seven elements were 216.9, 213.8, 324.7, 267.7, 228.8, 231.6, and $189.0 \mathrm{~nm}$ for $\mathrm{Pb}, \mathrm{Zn}, \mathrm{Cu}, \mathrm{Cr}$, $\mathrm{Cd}, \mathrm{Ni}$, and As, respectively. Method detection limit
(MDL) was 0.0101, 0.0003, 0.0003, 0.0006, 0.0003, 0.0003 , and $0.0004 \mathrm{mg} \cdot \mathrm{L}^{-1}$ for $\mathrm{Pb}, \mathrm{Zn}, \mathrm{Cu}, \mathrm{Cr}, \mathrm{Cd}, \mathrm{Ni}$, and As, respectively. Take two soil samples, one was added with standard, the other not. Seven elements were continuously determined for six times, then recovery rate was calculated, taking soil standard sample GSS-6 as quality control sample. The results show that the recovery rate of $\mathrm{Pb}, \mathrm{Zn}, \mathrm{Cu}, \mathrm{Cr}, \mathrm{Cd}, \mathrm{Ni}$, and As was $101.2 \%, 101.1 \%, 93.3 \%, 96.1 \%, 96.2 \%$, $94.7 \%$, and $99.4 \%$, respectively.

\section{Assessment Index of PTEs}

Three indexes were used to assess the pollution level (calculation methods and evaluation indicators were listed in Table 1) [24]. In order to evaluate the pollution status of a single element we used the Nemerow pollution index $\left(\mathrm{PI}_{\mathrm{N}}\right)$, which takes both mean and maximum values into consideration, hence this index reflects environmental quality conditions scientifically and comprehensively [25]. The index of geo-accumulation $\left(\mathrm{I}_{\mathrm{geo}}\right)$ was also used to assess the pollution level of a single element. This method not only considers anthropogenic factors and environmental geochemistry background value, but also considers the influence of natural activities on the background values [26]. The comprehensive pollution of 7 PTEs in soils was evaluated by the potential ecological risk index (PERI) [27].

\section{Statistical Analysis}

Basic statistics of the raw data were carried out using SPSS 23.1 software. One-way analysis of variance (ANOVA) was carried out to determine the significant differences of PTEs among the different zones. 
Table 2. Descriptive statistics of soil PTE concentrations.

\begin{tabular}{|c|c|c|c|c|c|c|c|}
\hline Metal & Mean $\left(\mathrm{mg} \cdot \mathrm{kg}^{-1}\right)$ & Min $\left(\mathrm{mg} \cdot \mathrm{kg}^{-1}\right)$ & Max $\left(\mathrm{mg} \cdot \mathrm{kg}^{-1}\right)$ & $\mathrm{SD}$ & $\mathrm{BV}\left(\mathrm{mg} \cdot \mathrm{kg}^{-1}\right)$ & $\mathrm{S}\left(\mathrm{mg} \cdot \mathrm{kg}^{-1}\right)$ & $\mathrm{CV}(\%)$ \\
\hline $\mathrm{Pb}$ & 111.13 & 20.53 & 356.45 & 64.22 & 24.8 & 500 & 57.79 \\
\hline $\mathrm{Cd}$ & 1.11 & 0.10 & 3.75 & 0.85 & 0.19 & 1.0 & 76.46 \\
\hline $\mathrm{Cu}$ & 76.50 & 51.80 & 200.55 & 17.56 & 32.2 & 400 & 22.95 \\
\hline $\mathrm{Cr}$ & 89.52 & 25.78 & 659.95 & 67.96 & 59 & 400 & 75.92 \\
\hline $\mathrm{Zn}$ & 196.33 & 113.69 & 785.91 & 72.78 & 76.8 & 500 & 37.07 \\
\hline $\mathrm{Ni}$ & 53.13 & 29.63 & 234.95 & 28.13 & 35.00 & 200 & 52.94 \\
\hline $\mathrm{As}$ & 88.28 & 4.56 & 617.39 & 101.83 & 10.60 & 40 & 115.35 \\
\hline
\end{tabular}

Note: BV - background value; S - soil environmental quality standards of the People's Republic of China (grade III)

Comparisons of means were carried out by the least significant difference (LSD) at the 5\% level. Principle component analysis (PCA), Cluster analysis (CA) were used to identify the source of elements.

Kriging interpolation was applied to the data set for describing the spatial distribution of PTEs. Ordinary kriging with a proper correction from smoothing effect can be revitalized as a reliable estimation method that allows for better use of the available information [28]. This method provides a best linear unbiased estimation (points of certain value) method in mathematics for the object. Its plug has higher credibility when the data points were more [29].

\section{Results and Discussion}

\section{Concentrations of PTEs in the Study Area}

The descriptive statistics of the concentrations of PTEs in soils are listed in Table 2. The total concentrations of As in soils were extremely variable, ranging from 4.56 to $617.39 \mathrm{mg} \cdot \mathrm{kg}^{-1}$, with an average concentration of $88.28 \mathrm{mg} \cdot \mathrm{kg}^{-1}$. The As concentration in some soil sampling sites exceeded the background value (BV) [30], which indicated that As was mainly derived from an anthropological source. The total concentrations of $\mathrm{Cd}$ and $\mathrm{Cr}$ in soils were also very variable, ranging from 0.10 to $3.75 \mathrm{mg} \cdot \mathrm{kg}^{-1}$ and 25.78 to $659.95 \mathrm{mg} \cdot \mathrm{kg}^{-1}$, respectively, with average concentrations of $1.11 \mathrm{mg} \cdot \mathrm{kg}^{-1}$ and $89.52 \mathrm{mg} \cdot \mathrm{kg}^{-1}$, respectively. Maximum concentrations of $\mathrm{Cd}$ and $\mathrm{Cr}$ were about 20 and 11 times their BVs, which derived from an anthropological source. The concentrations of $\mathrm{Pb}$ and $\mathrm{Zn}$ in soils ranged from 20.53 to $356.45 \mathrm{mg} \cdot \mathrm{kg}^{-1}$, and 113.69 to $785.91 \mathrm{mg} \cdot \mathrm{kg}^{-1}$, respectively, with average values of $111.13 \mathrm{mg} \cdot \mathrm{kg}^{-1}$ and $196.33 \mathrm{mg} \cdot \mathrm{kg}^{-1}$. The concentrations of $\mathrm{Pb}$ and $\mathrm{Zn}$ in the soils also exceeded their BVs, and maximum concentrations of $\mathrm{Pb}$ and $\mathrm{Zn}$ were about 14 and 10 times their BVs. Highest concentrations of $\mathrm{Ni}$ and $\mathrm{Cu}$ were about 7 and 6 times their BVs, respectively, which indicated that the soils in the local area mainly derived from an 87anthropogenic source.

\section{Sources of PTEs in the Study Area}

The results of PTE concentrations in different function zones were presented in Table 3. The higher concentrations of $\mathrm{Pb}, \mathrm{Cd}, \mathrm{Cr}, \mathrm{Ni}$, and $\mathrm{As}$ were all distributed in RGB and US. These two function zones were mainly polluted by vehicle exhaust emissions and industrial dust. $\mathrm{Pb}$ and $\mathrm{Cd}$ were mainly controlled by traffic activities (e.g., brake wear, tire wear, automobile exhaust) with high contamination levels found near traffic-intensive areas [31]. The $\mathrm{Yu}$ et al. report on the Mukal et al. also revealed that the sources of urban lead pollution in China were mainly leaded gasoline, industrial emissions, and coal dust [34]. The research on heavy metals in Zhangzhou city showed that $\mathrm{Pb}$ and $\mathrm{Cd}$ elements were disturbed by anthropogenic contributions [35]. Extreme sediment contamination in As was observed in industrial mining areas at Afrma [36], while $\mathrm{Cr}$ and $\mathrm{Ni}$ may also originate from industrial dust, since maximum values were much higher than their BVs. Tume et al. had the same conclusion [37]. On the other hand, Vince et al. and Manta et al. reported that $\mathrm{Cr}$ and $\mathrm{Ni}$ were primarily of lithogenic origin $[38,39]$. The higher concentration of $\mathrm{Zn}$ distributed in RG expect RGB and US, which indicated that daily life emissions may also lead to $\mathrm{Zn}$ accumulation in topsoil. Although there were no significant difference between 6 function zones, the highest concentration was distributed in UG, $\mathrm{RG}$, and IG, therefore fertilizer and sewage irrigation may be the cause of the accumulation of copper in the soil. Because concentrations of 7 PETs were higher than their BVs, PET pollution of this area was caused by anthropogenic input.

The results of PCA for total metal concentration in soil were shown in Fig. 2. Three principal component (PC) with eigenvalues higher than 1 were extracted. The associations between metals were displayed in Fig. 2. PCA leads to a reduction of the initial dimension of the dataset to three components, which explained $72.79 \%$ of the data variation.

The initial component matrix showed that $\mathrm{Ni}$ and $\mathrm{Cr}$ were associated with the first component (PC1), which explained $34.99 \%$ of the variance (Fig. 2). Industrial 
Table 3. PTE concentrations in different function zones $\left(\mathrm{mg} \cdot \mathrm{kg}^{-1}\right)$.

\begin{tabular}{|c|c|c|c|c|c|c|c|}
\hline $\begin{array}{c}\text { Function } \\
\text { zones }\end{array}$ & $\begin{array}{c}\mathrm{Pb} \\
(\mathrm{M} \pm \mathrm{SD})\end{array}$ & $\begin{array}{c}\mathrm{Cd} \\
(\mathrm{M} \pm \mathrm{SD})\end{array}$ & $\begin{array}{c}\mathrm{Cu} \\
(\mathrm{M} \pm \mathrm{SD})\end{array}$ & $\begin{array}{c}\mathrm{Cr} \\
(\mathrm{M} \pm \mathrm{SD})\end{array}$ & $\begin{array}{c}\mathrm{Zn} \\
(\mathrm{M} \pm \mathrm{SD})\end{array}$ & $\begin{array}{c}\mathrm{Ni} \\
(\mathrm{M} \pm \mathrm{SD})\end{array}$ & $\begin{array}{c}\text { As } \\
(\mathrm{M} \pm \mathrm{SD})\end{array}$ \\
\hline RG & $91.76 \pm 34.28 \mathrm{~b}$ & $1.05 \pm 0.96 \mathrm{~b}$ & $78.03 \pm 18.90 \mathrm{a}$ & $74.07 \pm 13.25 \mathrm{ab}$ & $197.36 \pm 85.94 \mathrm{~b}$ & $48.17 \pm 10.07 \mathrm{ab}$ & $61.71 \pm 41.66 \mathrm{~b}$ \\
\hline $\mathrm{UG}$ & $154.05 \pm 59.63 \mathrm{a}$ & $1.20 \pm 0.67 \mathrm{ab}$ & $79.72 \pm 14.42 \mathrm{a}$ & $82.86 \pm 27.24 \mathrm{ab}$ & $189.30 \pm 26.70 \mathrm{~b}$ & $47.15 \pm 6.88 \mathrm{ab}$ & $74.81 \pm 116.72 \mathrm{~b}$ \\
\hline $\mathrm{US}$ & $157.34 \pm 82.31 \mathrm{a}$ & $1.52 \pm 0.80 \mathrm{a}$ & $75.50 \pm 22.42 \mathrm{a}$ & $86.93 \pm 16.74 \mathrm{ab}$ & $243.70 \pm 104.63 \mathrm{a}$ & $55.80 \pm 21.07 \mathrm{ab}$ & $179.61 \pm 138.31 \mathrm{a}$ \\
\hline RGB & $167.53 \pm 86.90 \mathrm{a}$ & $1.68 \pm 0.89 \mathrm{a}$ & $73.00 \pm 18.30 \mathrm{a}$ & $111.12 \pm 99.26 \mathrm{a}$ & $202.54 \pm 56.01 \mathrm{ab}$ & $61.02 \pm 40.11 \mathrm{a}$ & $138.80 \pm 45.04 \mathrm{ab}$ \\
\hline URF & $91.09 \pm 51.20 \mathrm{~b}$ & $1.01 \pm 0.80 \mathrm{~b}$ & $70.25 \pm 4.00 \mathrm{a}$ & $65.79 \pm 24.95 \mathrm{~b}$ & $167.95 \pm 23.08 \mathrm{~b}$ & $46.85 \pm 9.98 \mathrm{~b}$ & $50.56 \pm 17.10 \mathrm{~b}$ \\
\hline IG & $107.77 \pm 62.82 \mathrm{~b}$ & $0.77 \pm 0.69 \mathrm{~b}$ & $77.96 \pm 18.36 \mathrm{a}$ & $73.82 \pm 6.92 \mathrm{~b}$ & $186.52 \pm 46.05 \mathrm{~b}$ & $41.72 \pm 4.55 \mathrm{~b}$ & $88.18 \pm 82.69 \mathrm{~b}$ \\
\hline
\end{tabular}

Note: Data in the table are the Means \pm SD; the different normal letters in the same column indicate significant difference among different function zones $(P<0.05)$. RGB: road green belt; US: urban square; UG: urban garden; IG: institution greenland; RG: residental greenland; UF: urban rural forest.

origin could be presumed for these two elements, since the highest concentration of $\mathrm{Cr}$ and $\mathrm{Ni}$ was found in the northern industrial zones. This result was consistent with Chen et al., who found that $\mathrm{Cr}$ and $\mathrm{Ni}$ were mainly from industrial activities [40], and $\mathrm{Cr}$ and $\mathrm{Ni}$ in soils of industrial townships also originated from industrial emissions [41].

Another component (PC2), which included $\mathrm{Cd}$, $\mathrm{Pb}$, and $\mathrm{As}$ and explained $22 \%$ of the variance, was identified according to their coefficients in component matrix (Fig. 2). Traffic origin was deduced for these elements, since the highest concentrations of $\mathrm{Cd}, \mathrm{Pb}$, and As were found in the central business zones with heavy traffic. The concentrations of $\mathrm{Pb}$ and $\mathrm{Cd}$ were higher in roadside areas than other areas in Beijing, which indicated that $\mathrm{Pb}$ and $\mathrm{Cd}$ were mainly from traffic sources [42]. Acosta et al. used multivariable analysis to identify the sources of $\mathrm{Pb}$ and $\mathrm{Cd}$ in soils, which were anthropogenic activities - specifically industrial activities and traffic [43].

The third component (PC3) which included $\mathrm{Cu}$ and $\mathrm{Zn}$ and explained $15.8 \%$ of the variance, was identified, according to their coefficients in component matrix (Fig. 2). Fertilizer origin was speculated for these two metals, since the highest concentrations of $\mathrm{Cu}$ and $\mathrm{Zn}$ were found scattered in all areas, and the anthropogenic source of $\mathrm{Cu}$ and $\mathrm{Zn}$ were pesticides and fertilizer [44], the green rate of Nanjing is as high as $45 \%$, with many green areas scattered across the city, and large amounts of fertilizer and pesticides are put into the soil every year, which may lead to the accumulation of $\mathrm{Cu}$ and $\mathrm{Zn}$.

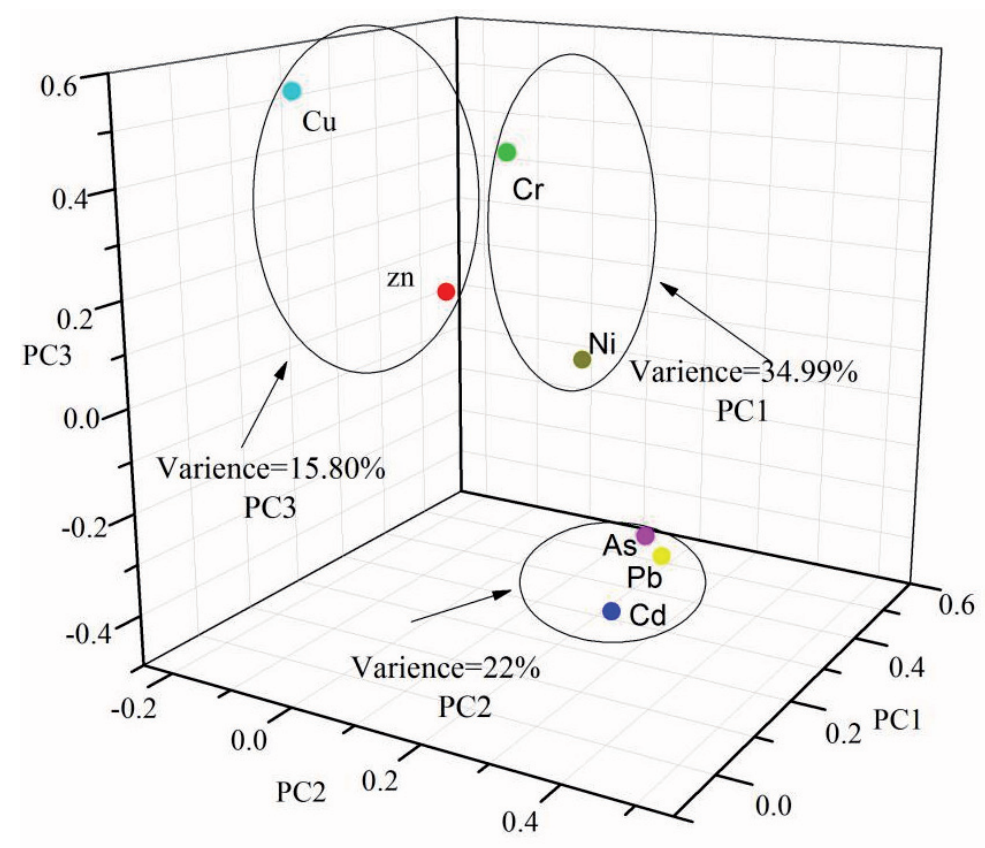

Fig. 2. 3-D plot of PCA loading for 7 PTEs in urban forest soils of Nanjing. Note: The numbers represent the variations explained by each principle component. 


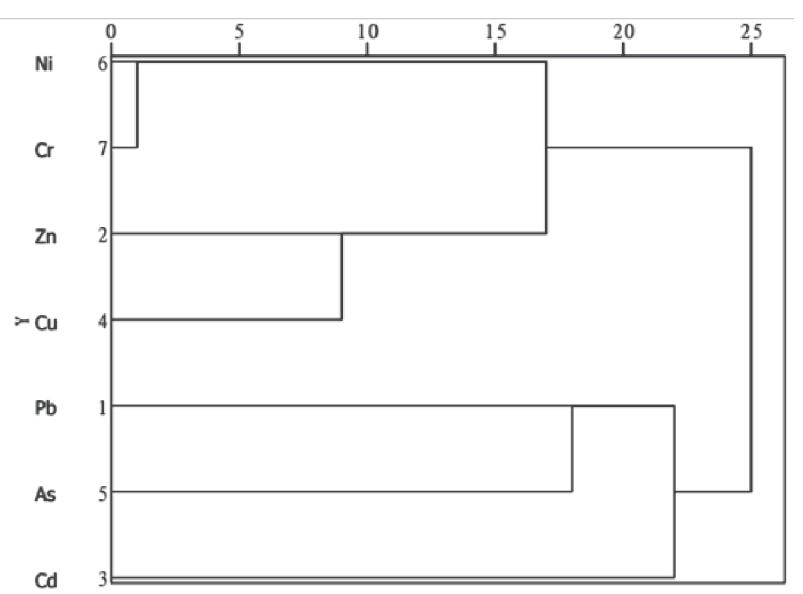

Fig. 3. Cluster analysis of 7 PTEs in urban forest soils of Nanjing.

Cluster analysis (CA) was often coupled with PCA to confirm results and provide grouping of variances (Fig. 3). In total, three clusters were observed: $\mathrm{Ni}-\mathrm{Cr}$, $\mathrm{Pb}-\mathrm{As}-\mathrm{Cd}$, and $\mathrm{Cu}-\mathrm{Zn}$. Thus, $\mathrm{CA}$ suggested at least three different sources of heavy metals in urban forest soils, which was in agreement with the PCA results.

\section{Pollution Assessment of PTEs in the Study Area}

PIN, $I_{\text {geo }}$, and PERI were used to evaluate the pollution status of 7 heavy metals and the results are shown in Table 4. $\mathrm{PI}_{\mathrm{N}}$ using background value for reference showing the pollution conditions in the order of $\mathrm{As}>\mathrm{Cd}>\mathrm{Pb}>\mathrm{Cr}>\mathrm{Zn}>\mathrm{Ni}>\mathrm{Cu}$, with $\mathrm{I}_{\text {geo }}$ indicating that As was in moderate pollution level with a value of 2.47, whereas the other 6 metals were in clean-light pollution level. PERI showed that the study area was in significant pollution level with value of 305.62. From Table 5 we found that $\mathrm{Pb}$ was in significant correlation with As $(P<0.01)$, and $\mathrm{Ni}$ and $\mathrm{Cr}$ were also in significant correlation with As $(P<0.01)$ when $\mathrm{Cu}$ was significantly correlated with $\mathrm{Zn}(P<0.01)$. RI was in significant correlation with $\mathrm{Cd}, \mathrm{As}, \mathrm{Pb}$, and $\mathrm{Zn}(P<0.01)$, which means that the pollution source of this study area was mainly traffic origin.

Table 4. The result of pollution indices of 7 PTEs in the sampling sites.

\begin{tabular}{|c|c|c|c|c|c|c|c|c|}
\hline \multirow[b]{2}{*}{ Element } & \multicolumn{2}{|c|}{$\mathrm{P}_{\text {in }}$} & \multicolumn{2}{|r|}{$\mathrm{I}_{\mathrm{geo}}$} & \multicolumn{4}{|c|}{ PERI } \\
\hline & $\begin{array}{c}\text { Use BV } \\
\text { as reference }\end{array}$ & $\begin{array}{c}\text { Use } \mathrm{S} \\
\text { as reference }\end{array}$ & Value & Pollution level & $\mathrm{Ti}$ & $\mathrm{Ei}$ & PERI & Level \\
\hline $\mathrm{Pb}$ & 10.65 & 0.53 & 1.58 & Clean-light pollution & 5 & 22.41 & \multirow{7}{*}{305.62} & \multirow{7}{*}{$\begin{array}{l}\text { Significant pol- } \\
\text { lution }\end{array}$} \\
\hline $\mathrm{Cd}$ & 14.55 & 2.77 & 1.96 & Clean-light pollution & 30 & 174.88 & & \\
\hline $\mathrm{Cu}$ & 4.71 & 0.38 & 0.66 & Clean-light pollution & 5 & 11.88 & & \\
\hline $\mathrm{Cr}$ & 7.98 & 1.57 & 1.17 & Clean-light pollution & 2 & 3.03 & & \\
\hline $\mathrm{Zn}$ & 7.46 & 1.15 & 0.77 & Clean-light pollution & 1 & 2.56 & & \\
\hline $\mathrm{Ni}$ & 4.87 & 0.85 & 0.17 & Clean-light pollution & 5 & 7.59 & & \\
\hline As & 41.60 & 11.03 & 2.47 & Moderate pollution & 10 & 83.28 & & \\
\hline
\end{tabular}

Note: $P_{\text {in }}$ - Nemerow pollution index; I - geo-accumulation index; PERI - potentially ecological risk index. BV - background value of PTEs; S - soil environmental quality standards of the People's Republic of China (grade III). $\mathrm{T}_{\mathrm{i}}$ - toxic-response factor for PTE i.

Table 5. Correlative coefficient matrix of 7 PTEs and RI.

\begin{tabular}{|c|c|c|c|c|c|c|c|c|}
\hline Variate & $\mathrm{Pb}$ & $\mathrm{Zn}$ & $\mathrm{Cd}$ & $\mathrm{Cu}$ & $\mathrm{As}$ & $\mathrm{Ni}$ & $\mathrm{Cr}$ & $\mathrm{RI}$ \\
\hline $\mathrm{Pb}$ & 1 & & & & & & \\
\hline $\mathrm{Zn}$ & $.162^{*}$ & 1 & & & & & & \\
\hline $\mathrm{Cd}$ & .125 & .000 & 1 & & & & & \\
\hline $\mathrm{Cu}$ & -.036 & $.595^{* *}$ & -.121 & 1 & & & & \\
\hline $\mathrm{As}$ & $.257^{* *}$ & $.374^{* *}$ & .115 & -.095 & 1 & & & \\
\hline $\mathrm{Ni}$ & $-.156^{*}$ & $.346^{* *}$ & -.031 & $.336^{* *}$ & .000 & 1 & & \\
\hline $\mathrm{Cr}$ & $-.170^{*}$ & $.333^{* *}$ & -.027 & $.281^{* *}$ & .038 & $.916^{* *}$ & 1 & \\
\hline $\mathrm{RI}$ & $.302^{* *}$ & $.242^{* *}$ & $.825^{* *}$ & -.116 & $.650^{* *}$ & .007 & .028 & 1 \\
\hline
\end{tabular}

Note: ${ }^{*}$ means 2 elements had significant correlation at 0.01 level (1-tailed); ${ }^{* *}$ means 2 elements had significant correlation at 0.01 level (2-tailed). 


\section{Spatial Distribution of PTEs and PERI in the Study Area}

Kriging interpolation showed different spatial distribution patterns of PETs and PERI in the study area, and the results are presented in Fig. 4. There were 3 patterns for PETs and PERI. $\mathrm{Pb}, \mathrm{Cd}$, As, and PERI presented a similar island pattern that took traffic and the commercial center as a hot spot (TCIP), while $\mathrm{Cr}$ and $\mathrm{Ni}$ presented an island pattern that took chemical plants as a hotspot (CPIP), with $\mathrm{Cu}$ and $\mathrm{Zn}$ presenting a scattered point pattern (SPP). TCIP covered Nanjing Railway Station, Gulou-Xinjiekou District, and Xinzhuang overpass, where there was an urban commercial and cultural center with busy traffic and dense population, with high concentrations of $\mathrm{Pb}, \mathrm{Cd}$, and $\mathrm{As}$ in this region's soils derived from fuel combustion, road dust, and tire wear. Wang et al. found that soil concentration of As was the highest in Beijing urban soils [45]. Xu et al. pointed out that As and Cd contamination were significantly correlated with landscape patterns [46]. CPIP covered NingLuo Highway, Qixia Avenue, and

$118^{\circ} 44^{\prime} 0^{\prime \prime} \mathrm{E} \quad 118^{\circ} 48^{\prime} 0^{\prime \prime} \mathrm{E} \quad 118^{\circ} 52^{\prime} 0^{\prime \prime} \mathrm{E} \quad 118^{\circ} 56^{\prime} 0^{\prime \prime} \mathrm{E} \quad 119^{\circ} 0^{\prime} 0^{\prime \prime} \mathrm{E}$

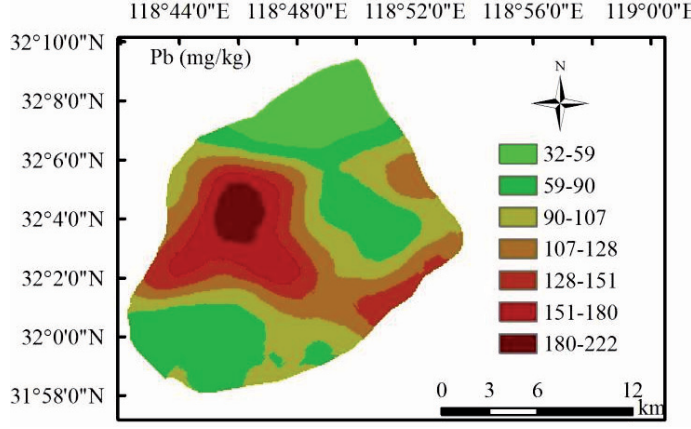

$118^{\circ} 44^{\prime} 0^{\prime \prime} \mathrm{E} \quad 118^{\circ} 48^{\prime} 0^{\prime \prime} \mathrm{E} \quad 118^{\circ} 52^{\prime} 00^{\prime \prime} \mathrm{E} \quad 118^{\circ} 56^{\circ} 0^{\prime \prime} \mathrm{E} \quad 119^{\circ} 0^{\prime} 0^{\prime \prime} \mathrm{E}$

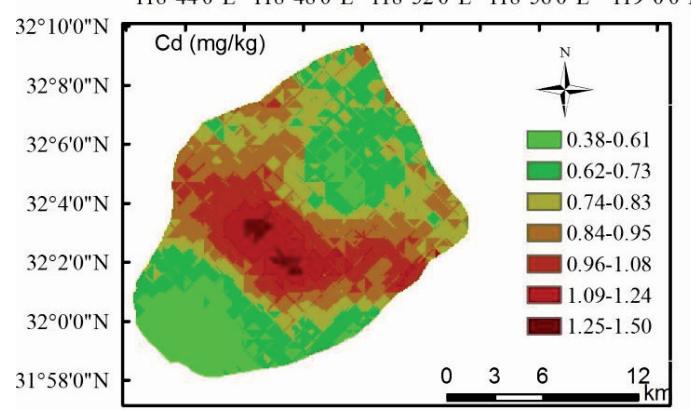

$118^{\circ} 44^{\prime} 0^{\prime \prime} \mathrm{E} \quad 118^{\circ} 48^{\prime} 0^{\prime \prime} \mathrm{E} \quad 118^{\circ} 52^{\prime} 0^{\prime \prime} \mathrm{E} \quad 118^{\circ} 56^{\prime} 0^{\prime \prime} \mathrm{E} \quad 119^{\circ} 0^{\prime} 0^{\prime \prime} \mathrm{E}$

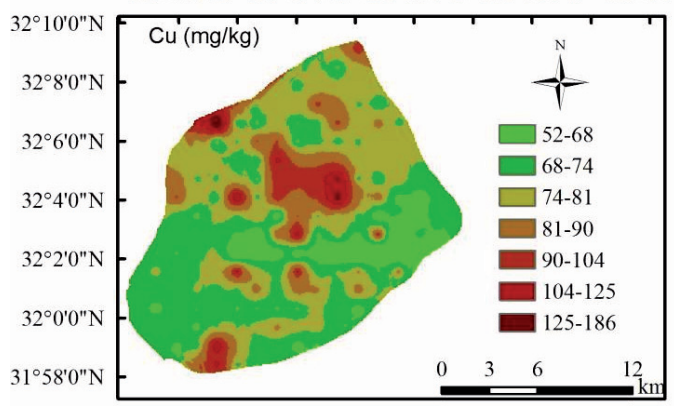

$118^{\circ} 44^{\prime} 0^{\prime \prime} \mathrm{E} \quad 118^{\circ} 48^{\prime} 0^{\prime \prime} \mathrm{E} \quad 118^{\circ} 52^{\prime} 0^{\prime \prime} \mathrm{E} \quad 118^{\circ} 56^{\prime} 00^{\prime \prime} \mathrm{E} \quad 119^{\circ} 0^{\prime} 0^{\prime \prime} \mathrm{E}$

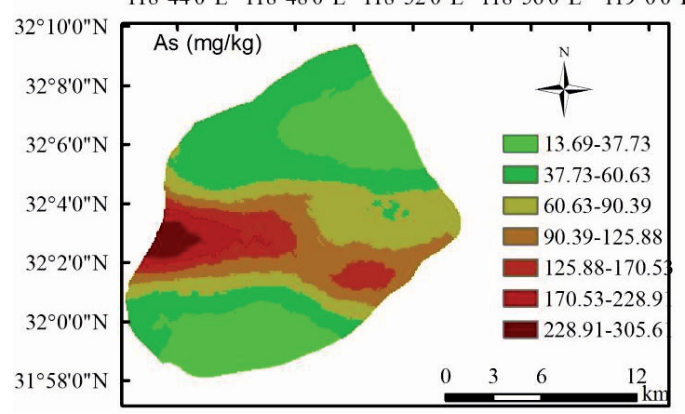

$118^{\circ} 44^{\prime} 0^{\prime \prime} \mathrm{E} \quad 118^{\circ} 48^{\prime} 0^{\prime \prime} \mathrm{E} \quad 118^{\circ} 52^{\prime} 0^{\prime \prime} \mathrm{E} \quad 118^{\circ} 56^{\prime} 0$ "E $\quad 119^{\circ} 0^{\prime} 0^{\prime \prime} \mathrm{E}$

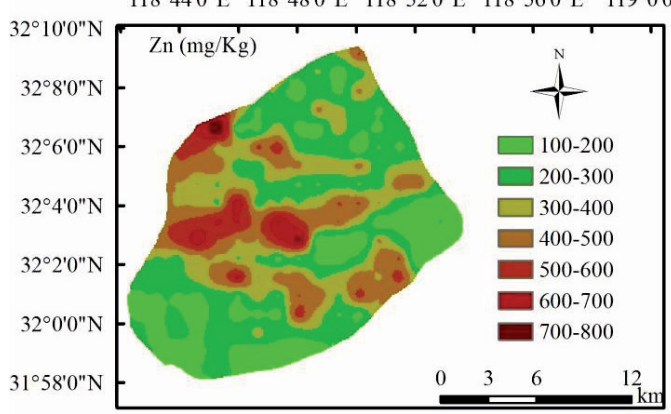

$118^{\circ} 44^{\prime} 0^{\prime \prime} \mathrm{E} \quad 118^{\circ} 48^{\prime} 0{ }^{\prime \prime} \mathrm{E} \quad 118^{\circ} 52^{\prime} 0^{\prime \prime} \mathrm{E} \quad 118^{\circ} 56^{\prime} 0^{\prime \prime} \mathrm{E} \quad 119^{\circ} 0^{\prime} 0$ "E
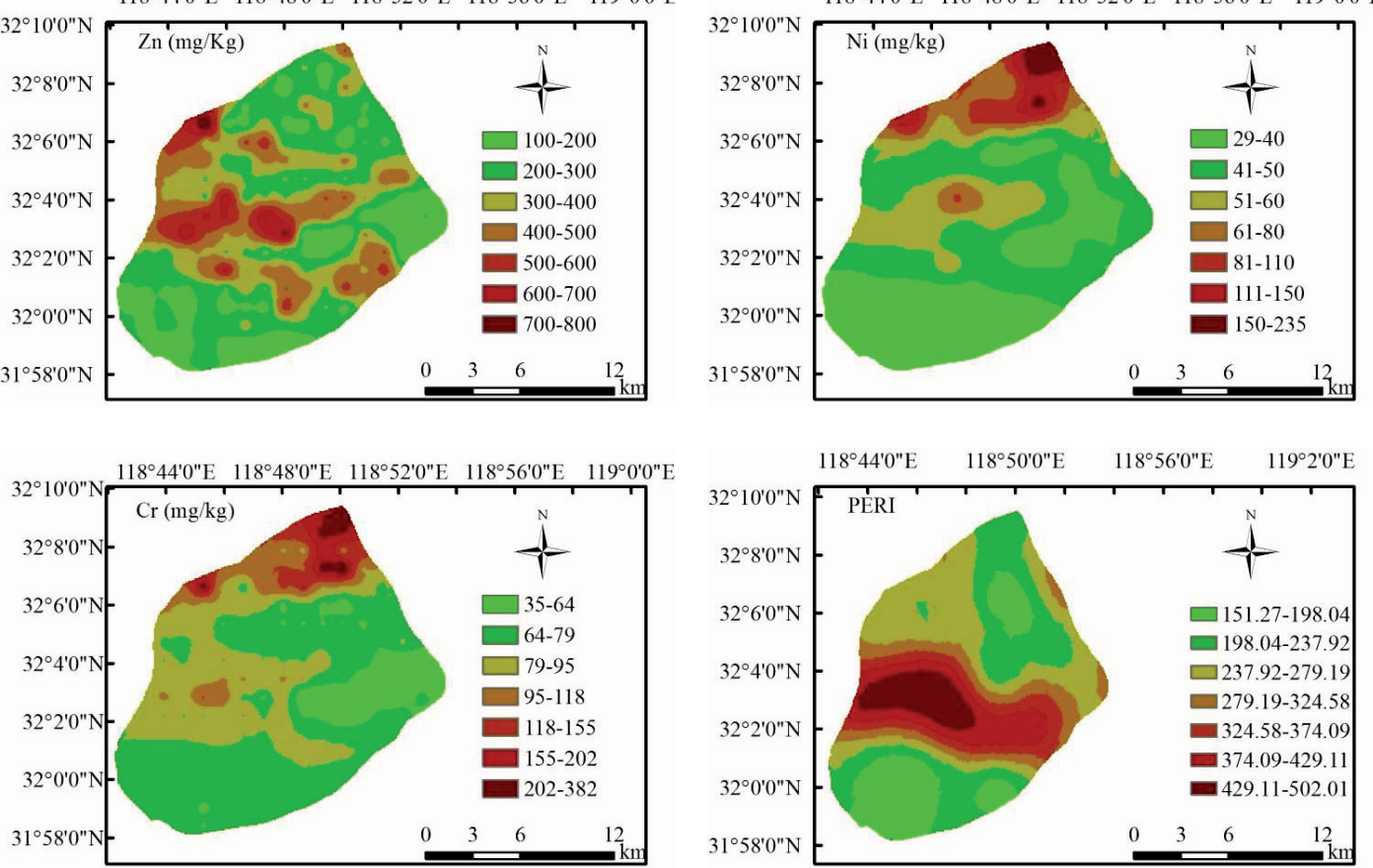

Fig. 4. Spatial distribution of PTEs and PERI in study area. 
Liutang overpass with many large chemical plants and gas stations in addition to heavy traffic. There were large numbers of equipment, instruments, and machinery production factories mainly producing electronic equipment and steel products, which were using $\mathrm{Cr}$ and $\mathrm{Ni}$ as raw materials. $\mathrm{Cr}$ and $\mathrm{Ni}$ in soil minerals were associated with a high correlation coefficient of $0.916(P<0.01)$, content of two elements affected by the common soil minerals. Hence, spatial structure and distribution of two elements had certain similarity. SPP was distributed widely in the area of the city, especially in the central and northern parts of the city, presented by an irregular dot. Therefore, zinc and copper pollution were caused not only by traffic and industrial origin, but also by pesticide, fertilizer, and sewage irrigation widely used in greening and daily life waste. Many researchers revealed that fertilizer with high content of $\mathrm{Cu}$ and $\mathrm{Zn}$ was a source of long-term soil contamination [47-49]. Spatial distribution characteristics of metals in the study area suggested that seven elements in urban forest soils of Nanjing were anthropogenic sources: industrial origin, traffic origin, fertilizer and pesticides, which were in total agreement with the PAC and CA results.

\section{Conclusions}

Concentrations of 7 PTEs in Nanjing urban forest soils were heterogeneity and all higher than their BVs, especially for $\mathrm{As}$ and $\mathrm{Cd}$, whose mean values were 8.7 and 5.8 times their BVs, respectively. Land type of the urban forest soils affected the metals accumulation in Nanjing. High concentrations of all elements were measured in RGB, US, and UG. PCA and $\mathrm{CA}$ identified $\mathrm{Pb}, \mathrm{As}$, and $\mathrm{Cd}$ as being mainly derived from traffic, $\mathrm{Ni}$ and $\mathrm{Cr}$ mainly from industrial origin, and $\mathrm{Zn}$ and $\mathrm{Cu}$ mainly from hree spatial distribution patterns of seven metals (CCIP, CNIP, and SPP) confirm the anthropogenic sources of Nanjing urban forest soils. As pollution was most serious in the study area, PERI of seven elements was 305.62 - in a state of significant pollution. High PERI value was mainly due to the high concentrations of $\mathrm{Pb}, \mathrm{Cd}, \mathrm{As}$, and $\mathrm{Zn}$ in the urban forest soils. Hence, pollution of PETs in Nanjing urban forest soil were mainly due to traffic emissions.

\section{Acknowledgements}

This study was supported financially by the National Natural Science Foundation of China (Nos. 31270664 and 31670615), the Research and Innovation Program for College Graduates of Jiangsu Province (No. CXZZ13_0533), and Priority Academic Program Development of Jiangsu Higher Education Institutions (PAPD), China.

\section{Conflict of Interest}

The authors declare no conflict of interest.

\section{References}

1. BRADL H.B. Adsorption of heavy metal ions on soils and soils constituents. Journal of Colloid and Interface Science. 1 (277), 1, 2004.

2. FACCHINEUI A., SACCHI E., MALLEN L. Multivariate statistical and GIS-based approach to identify heavy metals sources in soils. Environmental Pollution. 114 (3), 313, 2001.

3. KHAN A., KHAN S., KHAN M.A., QAMAR Z., WAQAS M. The uptake and bioaccumulation of heavy metals by food plants, their effects on plants nutrients, and associated health risk: a review. Environmental Science and Pollution Research. 22 (18), 13771, 2015.

4. ZOU C.Q., ZHANG Y.Q., RASHID A. Biofortification of wheat with zinc through zinc fertilization in seven countries. Plant and Soil. 361 (1-2), 119, 2012.

5. MALHI S.S., COWELL L., KUTCHER H.R. Relative effectiveness of various sources, methods, times and rates of copper fertilizers in improving grain yield of wheat on a $\mathrm{Cu}$-deficient soil. Canadian Journal of Plant Science. 85 (1), 59, 2005.

6. NIKOLI T., MATSI T. Evaluation of certain Ni soil tests for an initial estimation of Ni sufficiency critical levels. Journal of Plant Nutrition and Soil Science. 177 (4), 596, 2014.

7. SHANMUGAM V., LO J.C., YEH K.C. Control of Zn Uptake in Arabidopsis halleri: a balance between $\mathrm{Zn}$ and Fe. Frontiers in Plant Science. 4 (4), 281, 2013.

8. CHEN Y.H., NARA K., WEN Z.G. Growth and photosynthetic responses of ectomycorrhizal pine seedlings exposed to elevated $\mathrm{Cu}$ in soils. Mycorrhiza. 25(7), 561, 2015.

9. CHEN C.Y., HUANG D.J., LIU J.Q. Functions and toxicity of nickel in plants: recent advances and future prospects. Clean-Soil Air Water. 37 (4-5), 304, 2009.

10. HECHMI N., BEN A.N., ABDENNACEUR H., JEDIDI N. Phytoremadiation potential of Maize (Zea mays L.) in co-contaminated soils with pentachilorophenol and cadmium. International Journal of Phytoremediation. 15 (7), 703, 2013.

11. RAMANA S., BISWAS A.K., AJAY. Potential of Mestha (Hibiscus sabdarifa) for Remediation of Soils Contaminated with Chromium. Journal of Natural Fibers. 13 (5), 597, 2016.

12. QUAGHEBEUR M., RENGEL Z. Arsenic speciation governs arsenic uptake and transport in terrestrial plants. Microchimica. Acta. 151 (3-4), 141, 2005.

13. SURIYAGODA L.D.B., DITTERT K., LAMBERS H. Mechanism of arsenic uptake, translocation and plant resistance to accumulate arsenic in rice grains. Agriculture Ecosystems \& Environment. 253, 23, 2018.

14. CHEN L., ZHOU S.L., SHI Y.X., WANG C.H., LI B.J., LI Y., WU S.H. Heavy metals in food crops, soil, and water in the Lihe River Watershed of the Taihu Region and their potential health risks when ingested. Science of the Total Environment. 615, 141, 2018

15. LIU H., YAN Z., XUE Z., YOU X., YI S., XU J. Source identification and spatial distribution of heavy metals in 
tobacco-growing soils in shandong province of china with multivariate and geostatistical analysis. Environmental Science \& Pollution Research. 24 (6), 5964, 2017.

16. SOENTGEN J. Arsenic. Environmental chemistry, health threats and waste treatment. GAIA-Ecological Perspectives for Science and Society. 20 (3), 199, 2011.

17. GUNEY M., ONAY T.T., COPTY N.K. Impact of overland traffic on heavy metal levels in highway dust and soils of Istanbul, Turkey. Environmental Monitoring and Assessment. 164 (1-4), 101, 2010.

18. MA L., YANG Z.G., LI L., WANG L. Source identification and risk assessment of heavy metal contaminations in urban soils of Changsha, a mine-impacted city in Southern China. Environmental Science \& Pollution Research. 23 (17), 17058, 2016.

19. HUANG Y., LI T.Q., WU C.X., HE Z.L., JAPENGA J., DENG M.H., YANG X. E. An integrated approach to assess heavy metal source apportionment in per-urban agricultural soils. Jourbal of Hazardous Materials. 299, 540,2015

20. LU J., JIAO W.B., QIU H.Y., CHEN B., HUANG X.X., KANG B. Origin and spatial distribution of heavy metals and carcinogenic risk assessment in mining areas at You'xi County southeast China. Geoderma. 310, 99, 2018.

21. SINGH V., JOSHI G.C., BISHT D. Energy dispersive x-ray fluorescent analysis of soil in the vicinity of industrial areas and heavy metal pollution assessment. Journal of Applied Spectroscopy. 84 (2), 306, 2017.

22. MORSELLI L., BRUSORI B., PASSARINI F., BERNARDI, E., FRANCAVIGLIA R., GATALETA L., MARCHIONNI M., AROMOLO R., BENEDETTI A., OLIVIERI P. Heavy metals monitoring at a mediterranean natural ecosystem of Central Italy. Trends in different environmental matrixes. Environment International. 30 (2), 173, 2004

23. BALLARBI M., RAIS N., ELSASS F., DUPLAY J., IJJAALI M. Speciation of $\mathrm{Cr}, \mathrm{Cu}, \mathrm{Ni}$ and $\mathrm{Zn}$ in soils irrigated with contaminated waters: A case study of agricultural soils from the plain of Saiss (Fez, Morocco). Environmental Earth Science. 73 (7), 465, 2015.

24. YI Y.J., YANG Z.F., ZHANG S.H. Ecological risk assessment of heavy metals in sediment and human health risk assessment of heavy metals in fishes in the middle and lower reaches of the Yangtze River basin. Environmental Pollution. 159, 2575, 2011.

25. SINGH V., JOSHI G.C., BISHT D. Energy dispersive x-ray fluorescent analysis of soil in the vicinity of industrial areas and heavy metal pollution assessment. Journal of Applied Spectroscopy. 84 (2), 306, 2017.

26. TEH T.L., RAHMAN N.N., SHAHADAT M., WONG Y.S., SYAKIR M.I., OMAR A. K. A comparative study of metal contamination in soil using the borehole method. Environmental Monitoring and Assessment. 188 (7), 404, 2016.

27. MAANAN M., SADDIK M., MAANAN M., CHAIBI M., ASSOBHEI O., ZOURARAH B. Environmental and ecological risk assessment of heavy metals in sediments of Nador lagoon, Morocco. Ecological Indicators. 48, 616, 2015.

28. YAMAMOTO J.K. Correcting the smoothing effect of ordinary kriging estimates. Mathematical Geology. 37 (1), 69, 2005.

29. XIE Y.F., CHEN T.B., LEI M., YANG J., GUO Q.J., SONG B., ZHOU X.Y. Spatial distribution of soil heavy metal pollution estimated by different interpolation methods: accuracy and uncertainty analysis. Chemosphere. 82 (3), 468, 2011.

30. The group of natural background values of soil, academia sinia. The natural background values of some trace elements in the important soil types of Beijing and Nanjing areas. Acta Pedologica Sinica, 16 (4), 319, 1979 [In Chinese].

31. YAN G., MAO L., LIU S., MAO Y., YE H., HUANG T., LI F., CHEN L. Enrichment and sources of trace metals in roadside soil in Shanghai, China: A case study of two urban/rural roads. Science of the Total Environment. 631632, 942, 2018.

32. YU G.M., XU J.Z., KANG S.C., ZHANG Q.G., HUANG J., REN Q., REN J.W., QIN D.H. Lead isotopic composition of insoluble particles from widespread mountain glaciers in western China: natural vs. anthropogenic sources. Atmospheric Environment. 75, 224, 2013.

33. ZHANG P., QIN C., HONG X., KANG G., QIN M., YANG D., PANG B., LI Y., HE J., DICK R.P. Risk assessment and source analysis of soil heavy metal pollution from lower reaches of Yellow Ricer irrigation in China. Science of the Total Environment. 633, 1136, 2018.

34. MUKAL H., TANAKA A., FUJJI T. Regional characteristic of sulfur and lead at several Chinese urban sites. Environmental Science \& Technol. 35, 1064, 2001.

35. CUI Z.A., QIAO S.Y., BAO Z.Y., WU N.Y. Contamination and distribution of heavy metals in urban and suburban soils in Zhangzhou City, Fujian, China. Environmental Earth Sciences. 64, 1607, 2011.

36. KINIMO K.C., YAO K.M., MARCOTTE S., KOUASSI N.L.B., TROKOUREY A. Distribution trends and ecological risks of arsentic and trace metals in wetland sediments around gold mining activities in centralsouthern and southeastern Cote d'lvoire. Journal of Geochemical Exploration. 190, 265, 2018.

37. TUME P., BECH J., SEPULVEDA B., TUME L., BECH J. Concentrations of heavy metals in urban soils of Talcahuano(Chile): a preliminary study. Environmental Monitoring and Assessment. 140, 91, 2008.

38. VINCE T., SZABO G., CSOMA Z., SANDOR G., SZABO S. The spatial distribution pattern of heavy metal concentrations in urban soils - a study of anthropogenic effects in Berehove, Ukraine. Open Geosciences. 6, 330, 2014.

39. MANTA D.S., ANGELONE M., BELLANCA A., NERI R., SPROVIERI M. Heavy metals in urban soils: a case study from the city of Palermo (Sicily), Italy. Science of the TotalEnvironment. 300, 229, 2002.

40. CHEN T., CHANG Q. R., LIU J., CLEVERS J.G.P. W., KOOISTRA L. Identification of soil heavy metal sources and improvement in spatial mapping based on soil spectral information: a case study in northwest China. Science of the Total Environment. 565, 155, 2016.

41. PATHAK A.K., KUMAR R., KUMAR P., YADAV S. Sources apportionment and spatio-temporal changes in metal pollution in surface and sub-surface soils of a mixed type industrial area in India. Journal of Geochemical Exploration. 159, 169, 2015.

42. XIA X.H., CHEN X., LIU R.M., LIU H. Heavy metals in urban soils with various types of land use in Beijing, China. Journal of Hazardous Materials. 186, 2043, 2011.

43. ACOSTA J.A., FA A., MARTINE-MARTINEZ S. Identification of heavy metal sources by multivariable analysis in a typical Mediterranean city (SE Spain). 
Environmental Monitoring and Assess. 169 (1-4), 519, 2010.

44. SZOLNOKI Z.S., FARSANG A., PUSKAS I. Cumulative impacts of human activities on urban garden soils: Origin and accumulation of metals. Environmental pollution. 177, 106, 2013.

45. WANG M., MARKET B., CHEN W.P., PENG C., OUYANG Z.Y. Identification of heavy metal pollutants using multivariate analysis and effects of land uses on their accumulation in urban soils in Beijing, China. Environmental Monitoring and Assess. 184, 5889, 2012.

46. XU L., LU A., WANG J., MA Z., PAN L., FENG X. Effect of land use type on metals accumulation and risk assessment in soil in the peri-urban area of beijing, china. Human and Ecological Risk Assessment. 22 (1), 265, 2016.
47. MOLINA M., ABURTO F., CALDERON R., CAZANGA M., ESCUDEY M. Trace element composition of selected fertilizers used in chile: phosphorus fertilizers as a source of long-term soil contamination. Journal of Soil Contamination. 18 (4), 497, 2009.

48. SHAN Y., TYSKLIND M., HAO F., OUYANG W., CHEN S., LIN C. Identification of sources of heavy metals in agricultural soils using multivariate analysis and gis. Journal of Soils and Sediments. 13 (4), 720, 2013.

49. LIU Y.Z., XIAO T.F., PERKINS R.B., ZHU J.M., ZHU Z. J., XIONG Y., NING Z.P. Geogenic cadmium pollution and potential health risks, with emphasis on black shale. Journal of Geochemical Exploration. 176, 42, 2017. 